\title{
Notulae to the Italian alien vascular flora: 7
}

Gabriele Galasso', Gianniantonio Domina², Nicola M.G. Ardenghi ${ }^{3}$,

Claudio Aristarchi ${ }^{4}$, Gianluigi Bacchetta ${ }^{5}$, Fabrizio Bartolucci ${ }^{6}$, Gianmaria Bonari ${ }^{7}$, Daniela Bouvet ${ }^{8}$, Giuseppe Brundu ${ }^{9}$, Sergio Buono ${ }^{10}$, Orazio Caldarella", Giacomo Calvia ${ }^{5}$, Ana Cano-Ortiz ${ }^{12}$, Emilio Corti ${ }^{13}$, Francesco S. D’Amico ${ }^{14}$, Marco D’Antraccoli ${ }^{15}$, Alessandra Di Turi ${ }^{4}$, Moreno Dutto $^{16}$, Emanuele Fanfarillo ${ }^{17}$, Giulio Ferretti ${ }^{13}$, Tiberio Fiaschi ${ }^{18}$, Claudia Ganz ${ }^{19}$, Riccardo Guarino ${ }^{20}$, Mauro Iberite ${ }^{17}$, Valentina L.A. Laface ${ }^{21}$, Alfonso La Rosa ${ }^{22}$, Lorenzo Lastrucci ${ }^{23}$, Marta Latini ${ }^{17}$, Lorenzo Lazzaro ${ }^{13}$, Michele Lonati ${ }^{24}$, Vanessa Lozano ${ }^{9}$, Fabio Luchino ${ }^{25}$, Sara Magrini ${ }^{26}$, Andrea Mainetti ${ }^{24}$, Manuela Manca ${ }^{27}$, Michele Mugnai ${ }^{13}$, Carmelo M. Musarella ${ }^{21}$, Gianluca Nicolella ${ }^{28}$, Nicola Olivieri ${ }^{29}$, Ines Orrù ${ }^{5}$, Gaetano Pazienza ${ }^{14}$, Lorenzo Peruzzi ${ }^{15}$, Lina Podda ${ }^{9}$, Filippo Prosser ${ }^{30}$, Simone Ravetto Enri ${ }^{24}$, Silvana Restivo ${ }^{31}$, Francesco Roma-Marzio ${ }^{32}$, Alessandro Ruggero ${ }^{33}$, Anna Scoppola ${ }^{34}$, Federico Selvi ${ }^{35}$, Giovanni Spampinato ${ }^{21}$, Adriano Stinca ${ }^{36}$, Massimo Terzi ${ }^{37}$, Manuel Tiburtini ${ }^{38}$, Emilia Tornatore ${ }^{39}$, Roberto Vetromile ${ }^{40}$, Chiara $\mathrm{Nepi}^{23}$

I Sezione di Botanica, Museo di Storia Naturale di Milano, Corso Venezia 55, 20121 Milano, Italy 2 Dipartimento di Scienze Agrarie, Alimentari e Forestali (SAAF), Università di Palermo, Viale delle Scienze, ed. 4, 90128 Palermo, Italy 3 Dipartimento di Scienze della Terra e dell'Ambiente, Università di Pavia, Via Sant'Epifanio 14, 27100 Pavia, Italy 4 Via Crocetta di Apparizione 32, 16133 Genova, Italy 5 Dipartimento di Scienze della Vita e dell'Ambiente, Università di Cagliari, Viale Sant'Ignazio da Laconi 13, 09123 Cagliari, Italy 6 Centro Ricerche Floristiche dell'Appennino (Università di Camerino - Parco Nazionale del Gran Sasso e Monti della Laga), San Colombo, 67021 Barisciano (L'Aquila), Italy 7 Department of Botany and Zoology, Masaryk University, Kotlárská 2, CZ-611 37 Brno, Czech Republic 8 Dipartimento di Scienze della Vita e Biologia dei Sistemi, Università di Torino, Viale P.A. Mattioli 25, 10125 Torino, Italy 9 Dipartimento di Agraria, Università di Sassari, Viale Italia 39, 07100 Sassari, Italy 10 Via XXV Aprile 6, 01010 Oriolo Romano (Viterbo), Italy I I Viale Maria Santissima Mediatrice 38, 90129 Palermo, Italy 12 Departamento de Biología Animal, Biología Vegetal y Ecología, Universidad de Jaén, Paraje las Lagunillas s/n, 23071 Jaén, Spain 13 Dipartimento di Biologia, Università di Firenze, Via G. La Pira 4, 50121 Firenze, Italy 14 Dipartimento di Biologia e Museo Orto Botanico, Università di Bari Aldo Moro, Via E. Orabona 4, 70125 Bari, Italy 15 Dipartimento di Biologia, Università di Pisa, Via Derna 1, 56126 Pisa, Italy 16 Via Papò 4, 12039 Verzuolo (Cuneo), Italy 17 Dipartimento di Biologia Ambientale, Sapienza Università di Roma, Piazzale A. Moro 5, 00185 Roma, Italy 18 Dipartimento di Scienze della Vita, Università di Siena, Via P.A. Mattioli 4, 53100 Siena, Italy 19 Fraz. Perrière 78, 11027 Saint-Vincent (Aosta), Italy 20 Dipartimento di Scienze e Tecnologie Biologiche, Chimiche e Farmaceutiche (STEBICEF), Università di Palermo, Via Archirafi 20, 90123 Palermo, Italy 21 Dipartimento di Agraria, Università Mediterranea di Reggio Calabria, Feo di Vito

Copyright Gabriele Galasso et al. This is an open access article distributed under the terms of the Creative Commons Attribution License (CC BY 4.0), which permits unrestricted use, distribution, and reproduction in any medium, provided the original author and source are credited. 
snc, 89122 Reggio Calabria, Italy 22 Coop Silene a r.l., Via V. D'Ondes Reggio Vito 8/a, 90127 Palermo, Italy 23 Sistema Museale di Ateneo, Università di Firenze, Via G. La Pira 4, 50121 Firenze, Italy 24 Dipartimento di Scienze Agrarie, Forestali e Alimentari (DISAFA), Università di Torino, Largo P. Braccini 1, 10095 Grugliasco (Torino), Italy 25 Via Torrente Allume 6la, 98027 Roccalumera (Messina), Italy 26 Banca del Germoplasma della Tuscia, Università della Tuscia, Largo dell'Università snc, blocco c, 01100 Viterbo, Italy 27 Servizio Territoriale di Nuoro, Agenzia Fo.Re.S.T.A.S., Via A. Deffenu 7, 08100 Nuoro, Italy 28 Via di Valle Melaina 61, 00139 Roma, Italy 29 Via Maestri del Lavoro 40, 64100 Teramo, Italy 30 Fondazione Museo Civico di Rovereto, Largo Santa Caterina 41, 38068 Rovereto (Trento), Italy 31 Via J. Palach 63, 92025 Casteltermini (Agrigento), Italy 32 Sistema Museale di Ateneo, Università di Pisa, Via L. Ghini 13, 56126 Pisa, Italy 33 Loc. Parapinta, 07029 Tempio Pausania (Sassari), Italy 34 Dipartimento di Scienze Agrarie e Forestali (DAFNE), Università della Tuscia, Via San Camillo de Lellis snc, 01100 Viterbo, Italy 35 Dipartimento di Scienze delle Produzioni Agroalimentari e dell'Ambiente, Università di Firenze, Piazzale delle Cascine 28, 50144 Firenze, Italy 36 Dipartimento di Scienze e Tecnologie Ambientali, Biologiche e Farmaceutiche, Università della Campania Luigi Vanvitelli, Via A. Vivaldi 43, 81100 Caserta, Italy 37 Istituto di Bioscienze e Biorisorse, Consiglio Nazionale delle Ricerche (CNR-IBBR), Via G. Amendola 165/a, 70126 Bari, Italy 38 Via Madonna d'Ete 40, 63900 Fermo, Italy 39 Via Leo Longanesi 6, 90146 Palermo, Italy 40 Via Boccaccio 5, 80048 Sant'Anastasia (Napoli), Italy

Corresponding author: Gabriele Galasso (gabriele.galasso@comune.milano.it)

Academic editor: Stefania Biondi | Received 21 May 2019 | Accepted 27 May 2019 | Published 11 June 2019

Citation: Galasso G, Domina G, Ardenghi NMG, Aristarchi C, Bacchetta G, Bartolucci F, Bonari G, Bouvet D, Brundu G, Buono S, Caldarella O, Calvia G, Cano-Ortiz A, Corti E, D’Amico FS, D’Antraccoli M, Di Turi A, Dutto M, Fanfarillo E, Ferretti G, Fiaschi T, Ganz C, Guarino R, Iberite M, Laface VLA, La Rosa A, Lastrucci L, Latini M, Lazzaro L, Lonati M, Lozano V, Luchino F, Magrini S, Mainetti A, Manca M, Mugnai M, Musarella CM, Nicolella G, Olivieri N, Orrù I, Pazienza G, Peruzzi L, Podda L, Prosser F, Ravetto Enri S, Restivo S, Roma-Marzio F, Ruggero A, Scoppola A, Selvi F, Spampinato G, Stinca A, Terzi M, Tiburtini M, Tornatore E, Vetromile R, Nepi C (2019) Notulae to the Italian alien vascular flora: 7. Italian Botanist 7: 157-182. https://doi.org/10.3897/italianbotanist.7.36386

\begin{abstract}
In this contribution, new data concerning the distribution of vascular flora alien to Italy are presented. It includes new records, confirmations, and status changes for Italy or for Italian administrative regions of taxa in the genera Abies, Actinidia, Alooe, Amaryllis, Anredera, Arctotheca, Bidens, Cardiospermum, Celosia, Commelina, Cotoneaster, Cyclamen, Eclipta, Euphorbia, Grevillea, Hedera, Hibiscus, Impatiens, Juglans, Kalanchoe, Koelreuteria, Lindernia, Melinis, Myriophyllum, Nandina, Nicotiana, Oenothera, Oxalis, Parthenocissus, Phoenix, Phyllanthus, Physalis, Plumbago, Pteris, Quercus, Setaria, Symphytum, Tagetes, and Washingtonia. Nomenclatural and distribution updates, published elsewhere are provided as Suppl. material 1.
\end{abstract}

\title{
Keywords
}

Alien species, floristic data, Italy

\section{How to contribute}

The text for the new records should be submitted electronically to Chiara Nepi (chiara. nepi@unifi.it). The corresponding specimen along with its scan or photograph has to 
be sent to FI Herbarium: Museo di Storia Naturale (Botanica), Sistema Museale di Ateneo, Via G. La Pira 4, 50121 Firenze (Italy). Those texts concerning nomenclatural novelties (typifications only for accepted names), status changes, exclusions, and confirmations should be submitted electronically to: Gabriele Galasso (gabriele.galasso@ comune.milano.it). Each text should be within 2,000 characters (spaces included).

\section{Floristic records}

\section{Abies cephalonica Loudon (Pinaceae)}

+ (NAT) SAR: Tempio Pausania (Sassari), Cime del Limbara, abetaia Madonna della Neve (WGS84: 40.51057N; 9.10121E), abetaia, 30 January 1994, A. Ruggero (Herb. A. Ruggero); Tempio Pausania (Sassari), Monte Limbara, Punta Balestrieri (WGS84: $40.51035 \mathrm{~N} ; 9.10816 \mathrm{E})$, graniti ercinici, $1240-1260 \mathrm{~m}, 19$ January 2008, G. Bacchetta, A. Congiu (CAG); Berchidda (Sassari), Valle di Suprappare (WGS84: 40.841674N; 9.167793E), graniti, garighe, ericeti, rocce, $1132 \mathrm{~m}, 21$ May 2018, G. Calvia (FI, Herb. G. Calvia). - Naturalized alien species new for the flora of Sardegna.

This species is endemic to Greece, but it was introduced in other countries for reforestations (Farjon 2017). Recently it has been considered as naturalized in Friuli Venezia Giulia, Marche, Umbria, and casual in Abruzzo and Sicilia (Galasso et al. 2018a). In Sardegna, it was planted in several mountain areas starting from 1933 (Pavari and De Philippis 1941). In the Limbara massif (NE Sardegna), where many sparse patches of reforestations occur, this species is now naturalized, being found in garrigues, heaths and rocky places as far as $1 \mathrm{~km}$ far from plantation sites. Abundant presence of seedlings and saplings is observable nearby and inside the reforestations, and adult trees reach heights of 8-10 m. In the locality Badde Salighes (near Villa Piercy, Bolotana, Nuoro), this species was introduced for ornamental purposes.

G. Bacchetta, G. Calvia, A. Ruggero

\section{Actinidia deliciosa (A.Chev.) C.F.Liang \& A.R.Ferguson (Actinidiaceae)}

+ (CAS) LIG: Castiglione Chiavarese (Genova), impluvio sotto la cresta del Monte Merelle, versante N (WGS84: 44.25705N; 9.53501E), boscaglia igrofila, $424 \mathrm{~m}, 17$ June 2018, A. Di Turi, C. Aristarchi (FI, GDOR, GE). - Casual alien species new for the flora of Liguria.

It is a widely cultivated plant, native to East Asia, recorded in Italy as casual for Lombardia, Trentino-Alto Adige, Veneto, Emilia-Romagna, and Lazio (Galasso et al. 2018a). Well developed specimens have been found in two sites a few hundred metres away: in both cases they grow in hygrophilous stands with Alnus glutinosa (L.) Gaertn., Acer pseudoplatanus L., and Frangula alnus Mill. susbp alnus. The recorded area is located within the SAC IT1343412 "Deiva - Bracco - Pietra di Vasca - Mola".

A. Di Turi, C. Aristarchi 


\section{Alooe arborescens Mill. (Asphodelaceae)}

+ (CAS) PUG: Isole Tremiti (Foggia), Isola di San Domino, loc. Cameroni (WGS84: 42.116391N; 15.493383E), dirupo costiero colonizzato da Pinus halepensis, ca. $30 \mathrm{~m}$, 27 July 2018, N. Olivieri (FI). - Casual alien species new for the flora of Puglia.

Some individuals of this species grow under Pinus halepensis Mill. subsp. halepensis trees on a carbonate steep coastal cliff. The plants grow along with Mesembryanthemum cordifolium L.f. and Phagnalon rupestre (L.) DC. subsp. illyricum (H.Lindb.) Ginzb., on a little compact rock face exposed to East and partially shaded, not far from the sea. They may have originated by vegetative propagation from cultivated plants, used as ornamental in some surrounding private gardens. This species is frequently cultivated in the Mediterranean Italy and it is known as a casual alien in Liguria, Toscana, Lazio, Campania, and Basilicata, while it is naturalized in Sardegna (Galasso et al. 2018a).

N. Olivieri

\section{Amaryllis belladonna L. (Amaryllidaceae)}

+ (NAT) SIC: Savoca (Messina), loc. Pineta di Savoca (WGS84: 37.957310N; 15.338410E), sottobosco di un impianto forestale a Pinus pinea e Robinia pseudoacacia, 25 October 2018, F. Luchino (FI). - Naturalized alien species new for the flora of Sicilia. Amaryllis belladonna is native to South Africa, but it is now distributed in several tropical, subtropical, and temperate regions of the world (Govaerts et al. 2018). According to Galasso et al. (2018a), in southern Italy this species occurs in Campania, Puglia, and Calabria. Many individuals grow in a shady habitat in a reforestation with codominance of Pinus pinea L. and Robinia pseudoacacia L., near Savoca (Messina), possibly escaped from neighboring gardens or flowerbeds where this species is widely cultivated as ornamental. The population recorded here has been known for about 15 years and is constantly expanding. In Sicilia, this species occours also in Gibilmanna (Cefalù, Palermo: M. Barone, pers. obs.), Rabotano (Piazza Armerina, Enna: G. Messina, pers. obs.), Antillo (Messina: G. Coslovi, pers. obs.), Pizzo Castellana C.da San Guglielmo and along SS286 approximately at Km 1-2 (Castelbuono, Palermo: $A$. La Rosa, pers. obs.).

F. Luchino, O. Caldarella, A. La Rosa

\section{Anredera cordifolia (Ten.) Steenis (Basellaceae)}

+ (NAT) SAR. - Status change from casual to naturalized alien for the flora of Sardegna. Anredera cordifolia, originating from South America, is reported as invasive in Italy where, in the last 20 years, it became naturalized in many coastal areas (Pasta et al. 2016). This species was reported so far only as casual in Sardegna (Galasso et al. 2018a). Additional records are reported by Campus and De Pascali (2017) for Santa 
Teresa di Gallura, and for Sant'Antioco island in an abandoned field. During 2018, it was recorded as naturalized in three new sites: in the town of Nuoro, escaped from cultivation and covering about 50 square metres; along the shores of River Cedrino (Orosei); along roadsides in the locality San Giovanni (Posada).

M. Manca, G. Brundu

\section{Arctotheca prostrata (Salisb.) Britten (Asteraceae)}

+ (CAS) ITALIA (CAM): Napoli (Napoli), Parco Virgiliano (WGS84: 40.799727N; 14.180829E), sito erboso al margine del bosco di latifoglie, 142 m, 14 August 2018, A. Stinca, R. Vetromile (FI, PORUN-Herb. Stinca). - Casual alien species new for the flora of Italy (Campania).

Arctotheca prostrata is a South African perennial herb, showing long stolons rooting at nodes. This species has been introduced in other parts of the world, such as USA, Mexico, and Australia (Hinojosa-Espinosa and Villaseñor 2015), but it was not reported for Europe so far. The population recorded here covers an area of approximately $5 \mathrm{~m}^{2}$. A. prostrata is found in very disturbed grassland at a wood margin. This alien species was probably introduced via stolons in soil transportation. Specimens were identified according to Mahoney and McKenzie (2012).

A. Stinca, R. Vetromile

\section{Bidens subalternans DC. (Asteraceae)}

+ (NAT) TOS: Firenze (Firenze), stazione ferroviaria dello Statuto, binari (WGS84: $43.787222 \mathrm{~N} ; 11.250833 \mathrm{E}$ ), abbondante negli erbai ruderali fra i binari della ferrovia, 2 November 2018, F. Selvi (FI). - Naturalized alien species new for the flora of Toscana.

This Central-South American species occurs as an invasive neophyte in most Italian regions, from Friuli Venezia Giulia and Lombardia in the North to Sicilia in the South (Galasso et al. 2018a). It is part of ruderal communities in warm and xeric habitats close to urban areas, most commonly road margins, escarpments and railways, most often in sites showing Mediterranean or sub-Mediterranean climate. In Firenze, it grows abundantly along a relatively long stretch of the main national railway, from the station "Statuto" towards the eastern and southeastern outskirts of the town. It was still in flower and abundantly in fruit in October 2018.

F. Selvi

\section{Cardiospermum halicacabum L. (Sapindaceae)}

+ (CAS) PIE: Saluzzo (Cuneo), loc. Terre Rosse (WGS84: 44.641560N; 7.472558E), area collinare incolta vicino ad area boschiva, $369 \mathrm{~m}, 4$ October 2017, M. Dutto, G. Malfi (FI). - Casual alien species new for the flora of Piemonte. 
Cardiospermum halicacabum is a herbaceous perennial climbing plant native to the northern and tropical America. It is cultivated as an ornamental and may be found as naturalized in the warmer regions of southern Europe. In Italy it has been reported for the first time as a naturalized alien for Calabria and Sicilia, and as a casual for Sardegna (Galasso et al. 2018a). The cultivation in Piemonte is attested since the nineteenth century by some specimens preserved in TO: three specimens collected in the Turin Botanical Garden (from 1806 to 1921), a specimen cultivated in Alba (Cuneo), and four specimens without indication of the collecting site. In the recorded site five plants occur, in a second locality in Saluzzo [Saluzzo (Cuneo), loc. Terre Rosse (WGS84: $44.642030 \mathrm{~N} ; 7.472003 \mathrm{E}$ ), orto famigliare vicino a vecchio frutteto, $352 \mathrm{~m}, 4$ October 2017, M. Dutto], nine plants were observed. Flowering period goes from June to October and individuals produce an average of 3-4 fruits each. A thorough investigation was conducted between the fund owners and the residents in neighboring areas: the present or past cultivation of the species for ornamental purposes has not emerged and the people did not know it. Since studies based on bioclimatic modeling show a high potential for expansion (Gildenhuys et al. 2013), at the end of the growing season the specimens have been eradicated and the site will be monitored in the years to come.

M. Dutto, D. Bouvet

\section{Celosia argentea L. (Amaranthaceae)}

+ (CAS) PUG: Ugento (Lecce), fraz. Torre San Giovanni (WGS84: 39.875000N; 18.146813E), vegetazione disturbata al margine di una strada interpoderale presso la costa ionica, ca. 3 m, 21 August 2018, N. Olivieri (FI). - Casual alien species new for the flora of Puglia.

This species appears with some individuals in a disturbed vegetation, dominated by Phragmites australis (Cav.) Trin. ex Steud. subsp. australis, at the edge of a country road. The plants grow in a flat coastal area, on red soil with good water availability.

N. Olivieri

\section{Commelina erecta L. (Commelinaceae)}

+ (CAS) ITALIA (SIC): Palermo (Palermo), centro urbano, all'angolo tra Via M. Rapisardi e Via N. Morello (WGS84: 38.134187N; 13.343394E), marciapiede, 8 October 2018, O. Caldarella (FI). - Casual alien species new for the flora of Italy (Sicilia).

Commelina erecta is native to Central America (Faden 2000) and according to Kumar (2011) is currently distributed in Americas, tropical Africa, West Indies, Australia, and Asia. Israel is the only known place in the Mediterranean basin for this species, so far (Danin 2015). A few individuals grow in a sidewalk near a manhole, inside the fissure of lithic material of the gutter, probably originating from the glass or garden cultivation in the nearby dwellings.

O. Caldarella, A. La Rosa, F. Luchino, E. Tornatore 


\section{Cotoneaster pannosus Franch. (Rosaceae)}

+ (CAS) TOS: Bagno a Ripoli (Firenze), $2 \mathrm{~km}$ a E di Villamagna, lungo la strada sterrata che porta in loc. Torrino (WGS84: 43.76330N; 11.36026E), gariga e boscaglia meso-xerofila, 250 m, 21 July 2018, F. Roma-Marzio, L. Peruzzi (FI). - Casual alien species new for the flora of Toscana.

Cotoneaster pannosus is a popular ornamental evergreen shrub, native to China ( $\mathrm{Lu}$ and Brach 2003). It was introduced and escaped from cultivation in United States, Europe, South Africa, Pacific Islands (Hawaii and New Zealand), and Australia (Fryer et al. 2014). In Italy, C. pannosus was recorded as naturalized in Lombardia, and as casual in Trentino-Alto Adige, Liguria, and Puglia (Galasso et al. 2018a). We found one fruiting adult individual and two small plants along a pathway at the edge of a wood. Possibly, the plants originated from seeds of individuals cultivated in a country house placed in close proximity.

F. Roma-Marzio, L. Peruzzi

\section{Cyclamen persicum Mill. (Primulaceae)}

+ (CAS) ABR: Lanciano (Chieti), Via A. Cacciaguerra (WGS84: 42.229116N; 14.392751E), base del muro perimetrale di un edificio, ca. 285 m, 8 August 2018, $N$. Olivieri (FI). - Casual alien species new for the flora of Abruzzo.

A young individual of this species developed into a crevice at the base of the perimeter wall of a building, near a rain gutter downspout in a shaded site in the town. The plant may have originated from seeds produced by individuals grown as ornamental in neighboring buildings. Cyclamen persicum is a species native to South-Central Turkey, Syria, Lebanon, Israel, Jordan, the Greek islands of Crete, Rhodes and Karpathos, as well as to Algeria and Tunisia, now widely cultivated for ornamental purpose. In Italy, this species is reported as casual alien in Lombardia and Sardegna (Galasso et al. 2018a).

N. Olivieri

\section{Eclipta prostrata (L.) L. (Asteraceae)}

+ (NAT) LAZ. - Status change from casual to naturalized alien for the flora of Lazio.

This species, native to Asia, is a widely distributed and a common weed in warm temperate to tropical areas worldwide, where it grows commonly in moist places (Holm et al. 1977). It is considered casual alien in Lazio (Galasso et al. 2018a), distributed mainly along the Tyrrhenian coast from the municipality of Santa Marinella (Roma) to Formia (Latina) (Anzalone et al. 2010; Lucchese 2017). Based on recent observations, the species results naturalized on sandy soil along the coast of the Lake Bracciano (Roma), from the municipality of Anguillara Sabazia to Bracciano, and Trevignano Romano. In these sites, large populations occur with an important renewal. 


\section{Euphorbia davidii Subils (Euphorbiaceae)}

+ (NAT) TOS: Pontedera (Pisa), stazione ferroviaria di Pontedera-Casciana Terme (WGS84: 43.662113N; 10.629512E), tra i binari nella massicciata ferroviaria, $13 \mathrm{~m}$, 4 October 2018, G. Ferretti, M. Mugnai, E. Corti (FI); Grosseto (Grosseto), fraz. Alberese, stazione ferroviaria di Alberese Scalo (WGS84: 42.640182N; 11.134348E), nella massicciata ferroviaria in prossimità dei binari e nelle aree marginali, assieme a Euphorbia nutans, 23 m, 17 November 2018, M. Mugnai, S. Di Natale, L. Lazzaro, G. Ferretti (FI). - Naturalized alien species new for the flora of Toscana.

Euphorbia davidii is an alien species native to North America, usually retrieved along railways or in agricultural land (Viggiani 2015) and previously recorded only for northern Italy (Galasso et al. 2018a). We found two abundant populations in Pontedera and Alberese Scalo railway stations, located in the North and South of Tuscany, respectively. This distribution suggests the possible presence of other populations within the region and underlie the status of naturalized for the region.

M. Mugnai, E. Corti, L. Lazzaro, G. Ferretti

+ (NAT) LAZ: Ferentino (Frosinone), stazione ferroviaria (WGS84: 41.657718N; 13.245576E), tra i binari, $160 \mathrm{~m}, 16$ October 2017, E. Fanfarillo (RO); ibidem (WGS84: 41.65695N; 13.24635E), tra i binari, 160 m, 12 September 2018, E. Fanfarillo (FI, RO); Morolo (Frosinone), stazione ferroviaria (WGS84: 41.667064N; 13,194339E), abbondante tra i binari e sulle banchine, 160 m, 10 July 2018, E. Fanfarillo (FI, RO). - Naturalized alien species new for the flora of Lazio.

The population recorded in Ferentino was observed for the first time in October 2017; it appeared again, more conspicuous, in September 2018. In Morolo, this species was discovered in July 2018; it looks more abundant than in Ferentino and colonizes both the railways and the platforms. The invasive potential of this taxon (Marchessi et al. 2011) suggests that it needs to be constantly monitored.

E. Fanfarillo, G. Nicolella

\section{Grevillea robusta A.Cunn. ex R.Br. (Proteaceae)}

+ (CAS) LAZ: Roma (Roma), Via C. De Lollis (WGS84: 41.900975N; 12.515406E), interstizi tra muro e marciapiede, $47 \mathrm{~m}, 11$ June 2018, E. Fanfarillo (FI). - Casual alien species new for the flora of Lazio.

This species is cultivated as an ornamental tree along Via Cesare De Lollis, where every year it produces abundant flowers and fruits. Juveniles grow in the interstices between a wall and a sidewalk; rare seedlings were also observed in wall cracks.

E. Fanfarillo 


\section{Hedera hibernica (G.Kirchn.) Bean (Araliaceae)}

+ (NAT) PIE: Torino (Torino), Mirafiori Sud, bosco di ripa del Fiume Sangone, a valle della ciclopista del Sangone situata su Via Fratelli Bandiera (WGS84: 45.006917N; 7.655493E), bosco di ripa, ca. 230 m, 21 October 2018, M. Lonati, S. Ravetto Enri (FI); Grugliasco (Torino), area industriale di Strada del Portone, scarpate del sovrappasso ferroviario di Via Maserati, su entrambi i lati della ferrovia (WGS84: 45.046235N; 7.594065E), scarpata, ca. 275 m, 26 November 2018, M. Lonati, A. Mainetti (FI). Naturalized alien species new for the flora of Piemonte.

This is a ground cover plant frequently escaping from cultivation (McAllister and Rutherford 1990), reported in Italy for Lombardia, Trentino-Alto Adige, and Toscana (Galasso et al. 2018a). Both the above-mentioned populations form dense stands in the underwood of disturbed woodlands, already invaded by other alien species. The first one has colonized more than $300 \mathrm{~m}^{2}$ close to an illegal landfill of plant material from private gardens; the second one is about $100 \mathrm{~m}^{2}$, and originates from cut branches of a private hedge flowed on the Sangone river.

M. Lonati, S. Ravetto Enri, A. Mainetti

\section{Hibiscus syriacus L. (Malvaceae)}

+ (CAS) PUG: Brindisi (Brindisi), loc. Casale, presso Via Santa Maria del Casale (WGS84: 40.644697N; 17.941041E), base di muro ombroso, ca. 5 m, 23 August 2018, N. Olivieri (FI). - Casual alien species new for the flora of Puglia.

Some young plants grow together with ruderal vegetation at the base of a wall built with blocks of limestone and concrete, in a shady and rather humid area near the port of Brindisi. Nearby there are some enclosed gardens where the species could be cultivated and from which the seeds may have come. Hybiscus syriacus is known as a casual alien in Piemonte, Lombardia, Veneto, Emilia-Romagna, Trentino-Alto Adige, Friuli Venezia Giulia, Toscana, Marche, Umbria, Lazio, Abruzzo, Campania, and Sardegna (Galasso et al 2018a).

N. Olivieri

\section{Impatiens balsamina L. (Balsaminaceae)}

+ (CAS) LAZ: Alatri (Frosinone), Via Castagneto (WGS84: 41.735549N; 13.301030E), cunetta stradale, un solo individuo, 450 m, 24 July 2018, E. Fanfarillo (FI). - Casual alien species new for the flora of Lazio.

A single flowering individual was found growing in a grassy road ditch.

E. Fanfarillo 


\section{Juglans nigra L. (Juglandaceae)}

+ (CAS) ABR: Rocca di Mezzo (L'Aquila), loc. Colle del Morricone, ai margini dell'abitato (WGS84: 42.208438N; 13.511394E), incolto presso il bordo stradale, ca. $1290 \mathrm{~m}, 2$ August 2018, N. Olivieri (FI). - Casual alien species new for the flora of Abruzzo.

Some young individuals grow near the roadside on a rather deep calcareous soil in an uncultivated area occupied by disturbed vegetation dominated by shrubs such as Acer campestre L., A. pseudoplatanus L., Crataegus monogyna Jacq., and Prunus spinosa L. subsp. spinosa. Juglans nigra is cultivated as ornamental in private gardens located in the area and the young plants probably originate from seeds dispersed by zoochory. This species is native to the eastern regions of North America and was introduced in Italy in 1760 (Maniero 2015), where it is currently cultivated for the production of wood and for ornamental purposes in parks and along roads. It is known as a casual alien in Piemonte, Trentino-Alto Adige, Emilia-Romagna, Umbria, Lazio, Campania, and Sicilia, while it is naturalized in Lombardia and invasive in Veneto (Galasso et al 2018a).

N. Olivieri

\section{Kalanchooe xhoughtonii D.B.Ward (Crassulaceae)}

+ (NAT) LAZ: Roma (Roma), Municipio II, Via C. De Lollis, lato N, a fianco della fermata dell'autobus "de Lollis/Irpini" (WGS84: 41.901187N; 12.515989E), interstizio tra muro e marciapiede, 43 m, 10 September 2018, E. Fanfarillo (FI); ibidem, crepe nel cemento e fessure tra tubature, 43 m, 7 December 2018, N.M.G. Ardenghi (FI). - Naturalized alien nothospecies new for the flora of Lazio.

This ornamental nothotaxon is frequently cultivated in gardens and balconies and can easily escape into the wild by producing abundant, promptly radicating vegetative propagules (leaf-bulbils), so that it became invasive in some areas of the world (Ward 2008; Wang et al. 2016). Several young plants were observed growing in the interstices between a wall and a sidewalk, some of them emerging even from old infructescences of Casuarina equisetifolia L. spread on the ground. A group of larger, vigorous and unevenaged flowering individuals is present, at least since 2011 (as can be seen in pictures from Google Street View), at the top of the wall, growing within its cracks and nearby pipes.

E. Fanfarillo, N.M.G. Ardenghi

\section{Koelreuteria paniculata Laxm. (Sapindaceae)}

+ (CAS) TOS: Campiglia Marittima (Livorno), fraz. Venturina Terme (WGS84: $42.998797 \mathrm{~N} ; 10.516870 \mathrm{E})$, tra la strada e un campo abbandonato, $18 \mathrm{~m}, 21$ October 2017, T. Fiaschi (FI). - Casual alien species new to the flora of Toscana.

In our finding, the occurrence of this species is probably due to seed dispersed from private gardens. The escaped specimens currently found are about ten. Some of 
them reach two metres in height. Since the cultivation of Koelreuteria paniculata in the nearby garden of Villa Boldrini, where it fructifies regularly, dates back to the end of the Nineties (C. Bertozzi, in verbis), the number of seeds in the soil could be much higher than the observed developed individuals, due to the very efficient exogenous and endogenous dormancy of this (Rehman and Park 2000).

G. Bonari, T. Fiaschi, R. Guarino

\section{Lindernia dubia (L.) Pennell (Linderniaceae)}

+ (NAT) TAA: Bondone (Trento), sponda N del Lago d'Idro a W di Baitoni inferiore, loc. Rionda, $70 \mathrm{~m}$ a WSW della torretta di avvistamento (WGS84: 45.8048N; 10.5307E), sponda fangosa, $370 \mathrm{~m}, 27$ September 2018, F. Prosser, R. Vicentini, F. Valentini, R. Fedrizzi, M. Merli, det. F. Prosser (FI, ROV 74196). - Naturalized alien species new for the flora of Trentino-Alto Adige.

In locality of Rionda, this species forms a dense colony along about fifty metres of the shore, which can be estimated in some tens of thousands of specimens that at the observation date were in bloom and at the beginning of the fruiting. A second group of about fifty individuals was found $30 \mathrm{~m} \mathrm{NE}$ from the first record (ROV 74195). Both populations fall within the Nature 2000 "Lago d'Idro" area (IT3120065), where they could compete with the rare native Eleocharis acicularis (L.) Roem. \& Schult. Lindernia dubia is a species of North American origin reported in northern Italy as invasive in Piemonte and Lombardia, and naturalized in Veneto and Emilia-Romagna (Galasso et al. 2018a), where it occupies low altitude localities (Banfi and Galasso 2010). This observation confirms the ability of $L$. dubia to settle even within the Alpine chain, as already observed in Switzerland (Schoenenberger et al. 2014).

F. Prosser

\section{Melinis repens (Willd.) Zizka subsp. repens (Poaceae)}

+ (NAT) SAR: Pula (Cagliari), fraz. Santa Margherita di Pula, strada SS195 dal km 36,700 (WGS84: 39.950773N; 8.945784E), margini stradali su alluvioni quaternarie, 27 m, 14 November 2018, G. Bacchetta, G. Calvia, I. Orrù, L. Podda (FI, CAG). Naturalized alien subspecies new for the flora of Sardegna. Status change from casual to naturalized alien for the flora of Italy.

Melinis repens is a grass native to South Africa (Gibbs Russell et al. 1990), that has become a problematic weed in many tropical and subtropical regions around the world (Stokes et al. 2011), especially in South America, West Indies, and western Asia (Fish et al. 2015). Currently, it has been reported in Italy as a casual alien only for Campania (Galasso et al. 2018a). In Sardegna, it has been found along roadsides, probably escaped from cultivation due to the presence of ornamental plant nurseries.

G. Bacchetta, G. Calvia, I. Orrù, L. Podda 


\section{Myriophyllum aquaticum (Vell.) Verdc. (Haloragaceae)}

+ (INV) TOS. - Status change from naturalized to invasive alien for the flora of Toscana. Myriophyllum aquaticum (Parrot's feather) is a species native to tropical and subtropical America, widespread in many parts of the world (Lastrucci et al. 2017b). Due to its detrimental effects on invaded ecosystems this species is considered of Union concern according to the regulation (EU) No. 1143/2014 (European Commission 2014) and it is one of the 14 species enlisted in the list of invasive alien species (IAS) of Union concern occurring in Italy (and one of the 8 recorded for Toscana, Galasso et al. 2018a). Currently M. aquaticum is considered invasive for Piemonte and Veneto, and naturalized for other six Italian regions, including Toscana (Galasso et al. 2018a). It was recorded for the first time in this region by Lastrucci et al. (2006) at Lake Porta (Massa-Carrara province), where it was observed spreading across the network of canals around the lake, forming dense monophytic mats or penetrating in the autochtonous coenoses (Lastrucci et al. 2016). In this area, it has been showing a clear invasive behavior spreading in spite of the control actions adopted and exerting strong impacts on native vegetation due to competition (Lastrucci et al. 2017b). Furthermore, recently M. aquaticum has been recorded also in the provinces of Lucca and Pisa close to Lake Massaciuccoli (Peruzzi et al. 2016; Lastrucci et al. 2017a), and it was observed in October 2018 also close to Località Montuolo (Lucca province, WGS84: 43.838378N; 10.442848E). Considering the spread of this species in the regional range, but above all the impacts documented for Lake Porta in Lastrucci et al. (2017b), we retain most appropriate the status of invasive alien in Toscana for $M$. aquaticum.

L. Lazzaro, G. Ferretti, M. Mugnai, L. Lastrucci

\section{Nandina domestica Thunb. (Berberidaceae)}

+ (CAS) PUG: Lecce (Lecce), aiuola nella Villa Comunale "G. Garibaldi", nei pressi di Via XXV Luglio (WGS84: 40.354586N; 18.175833E), aiuola, ca. 49 m, 23 August 2018, N. Olivieri (FI). - Casual alien species new for the flora of Puglia.

Some young individuals of this species have developed in a flowerbed among the branches of Rhaphiolepis umbellata (Thunb.) Makino, in a semi-shaded position. These individuals are located in a site characterized by a microclimate cooler than the surrounding areas, due to the presence of numerous evergreen trees, including Quercus ilex L. subsp. ilex and Ficus elastica Roxb. ex Hornem. The young individuals of Nandina domestica originated from the fruits produced by some adult plants grown in another nearby flowerbed. This species is native to China and Japan and was introduced in Italy in 1821 (Maniero 2015), where it is currently widely cultivated as ornamental, due to the bright color of the foliage and berries.

N. Olivieri 


\section{Nicotiana glauca Graham (Solanaceae)}

+ (NAT) MAR: Fermo (Fermo), Viale XX Settembre, ai lati della strada (WGS84: $43.159477 \mathrm{~N}$; 13.715754E), margine stradale, argilla, in pieno suolo, ca. $230 \mathrm{~m}, 20$ August 2018, M. Tiburtini (PI 014835). - Naturalized alien species confirmed for the flora of Marche.

This species is recorded as invasive alien in Italy, known only for historical records in Marche (Galasso et al. 2018a). The plants are randomly distributed in the old town centre, where they grow in different places, either in soil or in cracks on the old walls of the town.

M. Tiburtini

\section{Oenothera lindheimeri (Engelm. \& A.Gray) W.L.Wagner \& Hoch (Onagraceae)}

+ (CAS) SIC: Casteltermini (Agrigento), Viale Santa Elisabetta (WGS84: 37.537778N; 13.652778E), avventizia in incolti, $515 \mathrm{~m}, 11$ October 2018, S. Restivo, det. R. Guarino (FI). - Casual alien species new for the flora of Sicilia.

Oenothera lindheimeri is a rhizomatous, vigorously growing herbaceous species native to southern Louisiana and Texas. So far, it has been recorded as invasive in California (Calflora 2018), Florida, Mississippi, Alabama (Darst and Gholson 2004), South Africa (McLean et al. 2018), Japan (Mito and Uesugi 2004), and China (Yan et al. 2014). In Europe, it has been recorded as casual alien in Portugal (Verloove and Sánchez Gullón 2012), Corsica (Tison 2012), Belgium (Rostański and Verloove 2015), Spain (Sánchez Gullón and Verloove 2015), Austria (Pflugbeil and Moosbrugger 2016), Greece (Raabe and Raus 2016), and Croatia (Pandža 2017). In Italy, it is recorded as a casual alien in Lombardia, Veneto, Campania, Puglia (Galasso et al. 2018a), Toscana (Galasso et al. 2018b), and Liguria (Ottonello and Longo 2018d). In our finding, the occurrence of this species is probably due to seed dispersal from private gardens nearby. It has been observed as adventitious also in eastern Sicilia, along roadsides in Fiumefreddo di Sicilia (Catania province, R. Guarino, pers. obs.).

S. Restivo, R. Guarino

\section{Oxalis debilis Kunth (Oxalidaceae)}

+ (CAS) LAZ: Roma (Roma), Municipio II, Piazza dei Siculi 2, scalinata davanti alla "Cooperativa la Risorgente" (WGS84: 41.899508N; 12.511471E), fessura alla base di gradini in marmo, 51 m, 7 December 2018, N.M.G. Ardenghi (FI). - Casual alien species confirmed for the flora of Lazio.

A single individual was found in Rome, within a crack at the base of marble steps. The presence of Oxalis debilis in Lazio was regarded as doubtful by Galasso et al. (2018a). 


\section{Parthenocissus tricuspidata (Siebold \& Zucc.) Planch. (Vitaceae)}

+ (NAT) BAS: Matera (Matera), Sasso Barisano, lungo una scalinata (WGS84: 40.666779N; 16.609984E), mura, ca. 400 m, 25 August 2018, L. Peruzzi, M. D'Antraccoli (FI). - Naturalized alien species new for the flora of Basilicata.

+ (NAT) PUG: Monopoli (Bari), c.da Gorgofreddo, Murgia barese, lungo la SP113, $250 \mathrm{~m}$ a N di Monte San Nicola (WGS84: 40.89721N; 17.28361E), costone roccioso calcareo a bordo strada, 190 m, 30 August 2018, F. Roma-Marzio, P. Liguori (FI, Herb. F. Roma-Marzio). - Naturalized alien species new for the flora of Puglia.

Parthenocissus tricuspidata is a vine commonly cultivated as ornamental, almost exclusively for wall cover (Verloove 2019) native to China, Japan, and Korea (Chen and Wen 2007). In Italy, it was reported as casual or naturalized in almost all the administrative regions except for Valle d'Aosta, Marche, Molise, Puglia, Basilicata, and Calabria (Galasso et al. 2018a). In Puglia, we found fruiting plants completely covering a limestone rocky ridge for about 200 meters. In Basilicata, we observed this species also growing abundantly along a road and above overpasses in the North edge of Matera (WGS84: 40.680404N; 16.587295E).

L. Peruzzi, M. D’Antraccoli, F. Roma-Marzio

\section{Phoenix roebelenii O’Brien (Arecaceae)}

+ (CAS) ITALIA (PUG): Brindisi (Brindisi), giardini pubblici di Piazza Vittorio Emanuele II (WGS84: 40.639861N; 17.948005E), giovani piante epifite sul tronco di piante adulte coltivate, ca. $2 \mathrm{~m}, 23$ August 2018, N. Olivieri (FI). - Casual alien species new for the flora of Italy (Puglia).

Some very young individuals have grown as epiphytes on the trunk of some adult plants of the same species, over $1.5 \mathrm{~m}$ tall, among which there is a female specimen. The young plants have developed among the residues of the leaf rachides, in the upper part of the stems. Phoenix roebelenii ripens the fruit and the young plants have developed from the seeds produced by the adult female individual. The species is native to southeastern Asia, from southwestern China to northern Laos and northern Vietnam, and now is a popular ornamental plant in the warm areas of the Mediterranean region, in the subtropical and tropical areas. The species has been identified according to Squire (2007) and Cullen et al. (2011).

N. Olivieri

\section{Phyllanthus tenellus Roxb. (Phyllanthaceae)}

+ (CAS) CAL: Villa San Giovanni (Reggio Calabria), fraz. Cannitello, in numerose fioriere con piante acquistate in vivaio, all'interno di una proprietà privata (WGS84: 
38.235556N; 15.660556E), fioriere, $11 \mathrm{~m}, 19$ September 2013, C.M. Musarella, det. C.M. Musarella, G. Spampinato (FI, REGGIO); Reggio Calabria (Reggio Calabria), Pellaro, proprietà privata (WGS84: 38.020000N; 15.643889E), dentro una fioriera, $11 \mathrm{~m}, 14$ August 2014, C.M. Musarella (REGGIO); ibidem, in un'aiuola e diffuso in un terreno incolto, $11 \mathrm{~m}, 6$ October 2018, C.M. Musarella (REGGIO); Reggio Calabria (Reggio Calabria), Arangea, vivaio, dentro vasi di alberi di mimosa provenienti dalla Sicilia (WGS84: 38.078056N; 15.663333E), vasi, 53 m, 23 August 2014, C.M. Musarella (REGGIO); Reggio Calabria (Reggio Calabria), Via Cardinale G. Portanova traversa Privata (WGS84: 38.115259N; 15.659431E), bordo strada, $63 \mathrm{~m}$, 14 September 2017, C.M. Musarella (REGGIO); Reggio Calabria (Reggio Calabria), Gallico Marina, lungo un muro di cinta all'interno di una proprietà privata (WGS84: 38.190833N; 15.646389E), base di muro, 24 m, 12 October 2018, V.L.A. Laface, det. V.L.A. Laface, C.M. Musarella, G. Spampinato (REGGIO). - Casual alien species new for the flora of Calabria.

Initially present as weed in nurseries and vases, this species first spread inside private properties and later along the city streets. Phyllanthus tenellus is native to Madagascar and Mauritius's Island, and it was found naturalized in Italy firstly in several localities of Messina (Crisafulli et al. 2011). Then, Galasso et al. (2016) reported it for Genova, and more recently Spadaro and Raimondo (2017) recorded some specimens in Palermo.

C.M. Musarella, V.L.A. Laface, A. Cano-Ortiz, G. Spampinato

\section{Physalis philadelphica Lam. (Solanaceae)}

+ (CAS) ITALIA (LAZ): Ferentino (Frosinone), loc. Fresine (WGS84: 41.663546N; 13.254221E), bordo strada, 205 m, 18 July 2018, E. Fanfarillo (FI, RO). - Casual alien species new for the flora of Italy (Lazio).

This species is an anciently cultivated plant from Mexico and Guatemala, so far reported in Europe for Austria, Belgium, Czech Republic, France, Lithuania, and Spain (DAISIE 2018). Some individuals, possibly escaped from nearby orchards, were found growing on a roadside. The risk of confusion with the closely related Physalis ixocarpa Brot. ex Hornem. is high in the determination of this taxon; the attribution of the collected specimens to $P$. philadelphica was especially based on the observation of a corolla longer than $10 \mathrm{~mm}$ and of twisted anthers about $4 \mathrm{~mm}$ long (Flora Zambesiaca 2018; New England Wild Flower Society 2018).

E. Fanfarillo

\section{Physalis viscosa L. (Solanaceae)}

+ (CAS) PUG: Bari (Bari), loc. Canale Lamasinata (WGS84: 41.090325N; 16.845230E), bordo strada, 40 m, 20 September 2018, G. Signorile, det. F.S. D’Amico (FI). - Casual alien species new for the flora of Puglia. 
Physalis viscosa is a South American species (Pignatti 2018) reported as a casual alien on the hills of Biella, in Piemonte (Soldano and Verloove 2013), and in the lower part of the River Biferno in Molise (Lucchese 2010). We observed some individuals of $P$. viscosa at the periphery of Bari, along the edge between a secondary road and the water drainage channel (i.e., Canale Lamasinata, locally called 'Canalone').

F.S. D’Amico, G. Pazienza, M. Terzi

\section{Plumbago auriculata Lam. (Plumbaginaceae)}

+ (CAS) PUG: Lecce (Lecce), Viale Gallipoli (WGS84: 40.348383N; 18.166944E), bordo di marciapiede, ca. $51 \mathrm{~m}, 23$ August 2018, N. Olivieri (FI). - Casual alien species new for the flora of Puglia.

Some young individuals of the species have developed among the inner edge of the sidewalks and the perimeter wall of a private garden. Individuals have developed into interstices between sidewalk cement and vertical masonry in a rather bright area exposed to the Northeast. Plumbago auriculata is cultivated as ornamental in the nearby gardens and individuals have developed from the seeds produced by cultivated plants.

N. Olivieri

\section{Pteris multifida Poir. (Pteridaceae)}

+ (CAS) LAZ: Roma (Roma), Villa Borghese, Giardino del Lago (WGS84: 41.914N; 12.484E \pm 200 m), muro umido, November 1949, A. Cacciato, rev. D. Marchetti (RO, scan in FI). - Casual alien species new for the flora of Lazio.

This pantropical species is cultivated as ornamental outside its native range and occurs as alien in northern Italy (Galasso et al. 2018a). The specimen, initially tentatively identified as Pteris cretica L., then revised by D. Marchetti in 1991, is the only record for peninsular Italy. According to B. Anzalone's personal notes, this specimen is to be surely referred to a population growing spontaneously that escaped from cultivation and colonized a humid wall. The growing site was recently surveyed again, but $P$. multifida has not been found.

G. Nicolella, M. Latini, M. Iberite

\section{Quercus rubra L. (Fagaceae)}

+ (CAS) LAZ: Roma (Roma), Villa Borghese, presso Viale dell'Uccelliera (WGS84: 41.913552N; 12.492622E), siepe di Laurus nobilis, ca. 50 m, 14 September 2018, N. Olivieri (FI). - Casual alien species new for the flora of Lazio.

Some very young individuals of this species have developed near a hedge of Laurus nobilis L., on soil formed by ancient pyroclastic deposits. In the area, there are several adult specimens of Quercus ilex L. subsp. ilex and Q. rubra L.. The latter species is 
native to the eastern regions of North America and was introduced in Italy in 1803 (Maniero 2015), as a forest species and as an ornamental, especially in the northern regions. This species is known as a casual alien in Liguria, Emilia-Romagna, TrentinoAlto Adige, Friuli Venezia Giulia, and Campania, while it is naturalized in Veneto and Puglia, and is invasive in Piemonte and Lombardia (Galasso et al. 2018a).

N. Olivieri

\section{Setaria parviflora (Poir.) Kerguélen (Poaceae)}

+ (NAT) SAR. - Status change from casual to naturalized alien for the flora of Sardegna.

In Iscra (Illorai, Sassari), along a country road connecting the SP17 route with SS129, Setaria parviflora is found as fully naturalised over a large area in natural and artificial pastures and along the roadside (WGS84: 40.320190N; 9.040872E), since 2016. It is a species originating from South America, recorded as naturalised or casual in Calabria, Campania, Emilia-Romagna, Lazio, Liguria, Lombardia, Marche, Puglia, Sicilia, Toscana, and Veneto. In Sardegna, it was reported as a casual alien (Galasso et al. 2018a).

G. Brundu, V. Lozano

\section{Symphytum asperum Lepech. (Boraginaceae)}

+ (NAT) TOS: Borgo San Lorenzo (Firenze), Mugello, fra Razzolo e la Colla di Casaglia, presso la locanda (WGS84: 44.040039N; 11.472939E), ca. 800 m, 23 June 1907, C. Sommier (FI); Firenze (Firenze), Cascine, inselvatichita a Scienza dell'Orticoltura (WGS84: 43.783903N; 11.220514E $\pm 100 \mathrm{~m}$ ), $42 \mathrm{~m}, 17$ May 1929, A. Fiori (FIAF 25094); Massa Marittima (Grosseto), fraz. Prata, strada per Gabellino dopo circa 1 km (WGS84: 43.074952N; 10.998783E), erbosi freschi lungo la strada, forse sfuggito a coltura per foraggio, ca. 500 m, 1 May 2017, F. Selvi 3801 (FI, Herb. F. Selvi); ibidem, 12 May 2018, F. Selvi 3898 (FI, Herb. F. Selvi). - Naturalized alien species confirmed for the flora of Toscana.

Since long time, this Pontic-Caucasian species has been widely introduced to Europe as ornamental and for forage production. In Italy, it occurs in the northern regions (Piemonte, Lombardia, Veneto, and Friuli Venezia Giulia) and, more southwards, in Marche (Galasso et al. 2018a). It was also collected in Borgo San Lorenzo by Sommier and in Firenze by Fiori (see also Cecchi and Selvi 2017), but here this species has not been observed in more recent times and it has probably disappeared. In the new site here reported, about 20 plants grow in a fresh meadow along the SS441, close to the junction with the SP54 "Cerro Balestro". At the time of collection, the plants were blooming and the pink-violet flowers were visited by bumble bees. Observations in spring 2018 confirmed the presence of this small population, which is therefore assumed to be naturalized. It was probably established from plants previously introduced in some local farm and cultivated for the production of forage. 


\section{Tagetes erecta L. (Asteraceae)}

+ (CAS) VDA: Châtillon (Aosta), strada di accesso al parcheggio comunale pluripiano di Via R. Pellissier (WGS84: 45.750247N; 7.614914E), bordo strada, ca. 520 m, 16 September 2017, C. Ganz (Herb. C. Ganz); Pont-Saint-Martin (Aosta), terrazzamento incolto (ex-vigneto) adiacente a Via A. Chenuil (WGS84: 45.601803N; 7.792190E), incolto, ca. 350 m, 29 September 2018, M. Lonati, A. Mainetti (FI). - Casual alien species new for the flora of Valle d'Aosta.

This Central and South American species (Everett 1982) is widely cultivated for ornamental purposes all over the world, and it is well known for its wide range of biological activities (Singh et al. 2003). In Italy, it was already known as casual alien for most of the regions, but not yet in Valle d'Aosta (north-western Italy), Marche, Umbria, Puglia, Basilicata, and Calabria (peninsular Italy) (Galasso et al. 2018a). The recorded plants probably originated from those cultivated in nearby private gardens, colonizing roadsides, asphalt cracks, and uncultivated areas. It has also been observed and photographed in the following localities: Saint-Vincent (Aosta), fraz. Moron, parcheggio principale della frazione (WGS84: 45.751497N; 7.666617E), bordo di parcheggio, ca. 805 m, 12 August 2016; Saint-Vincent (Aosta), fraz. Capard, parcheggio principale della frazione (WGS84: 45.756422N; 7.648353E), bordo di parcheggio, ca. $660 \mathrm{~m}$; Aymavilles (Aosta), capoluogo, poco sopra il cimitero comunale (WGS84: 45.700433N; 7.239597E), bordo strada, ca. 645 m, 3 September 2018; Saint-Vincent (Aosta), capoluogo in Via Prof. A. Ferré (WGS84: 45.749781N; 7.650753E), fessurazioni del marciapiede, ca. 565 m, 8 September 2018.

M. Lonati, C. Ganz, A. Mainetti

+ (CAS) PUG: Martina Franca (Taranto), Piazza Plebiscito lungo il perimetro della Basilica di San Martino (WGS84: 40.705467N; 17.336823E), marciapiede, 430 m, 26 August 2018, M. D’Antraccoli, F. Angeli (FI). - Casual alien species new for the flora of Puglia.

Possibly, the three detected individuals originated from seeds produced by plants cultivated in the centre of Martina Franca for ornamental purposes.

M. D’Antraccoli

\section{Washingtonia filifera (Linden ex André) H.Wendl. ex de Bary (Arecaceae)}

+ (CAS) ABR: Roseto degli Abruzzi (Teramo), presso il litorale adriatico in Viale Roma (WGS84: 42.680833N; 14.013888E), aiuola, ca. 9 m, E, 8 October 2018, N. Olivieri (FI). - Casual alien species new for the flora of Abruzzo.

Washingtonia filifera is a species native to southern California, southwestern Arizona and northern Mexico, cultivated in Italy, and known as a casual alien in Liguria, Campania and Sardegna, while it is naturalized in Sicilia (Galasso et al. 2018a). Some young individuals have developed on sandy soil, at the edge of a flowerbed located in the urban area 
near the Adriatic Sea, partially shaded by Pinus pinea L. and P. halepensis Mill. subsp. halepensis. They originate from the seeds produced by a tree growing in a nearby flowerbed.

N. Olivieri

+ (CAS) PUG: Lecce (Lecce), Villa Comunale "G. Garibaldi" nei pressi di Via A. Costa (WGS84: 40.354777N; 18.174555E), bordi di aiuole, 49 m, 23 August 2018, N. Olivieri (FI). - Casual alien species new for the flora of Puglia.

Some young individuals grow near the edges of flowerbeds and in cracks in the cement paving in an area located inside the Villa Comunale of Lecce. The young plants have grown from seeds produced by a tree found nearby.

N. Olivieri

\section{Nomenclatural and distribution updates from other literature sources}

Nomenclatural, status, and distribution updates according to Ross (1899), Chiovenda (1920), Cesca (1972), Viegi and Cela Renzoni (1981), Pedullà and Garbari (2002), Herman (2003), Raimondo et al. (2005), Nordenstam (2007), Domina and Mazzola (2008), Carine and Robba (2010), Arrigoni and Viegi (2011), Wood et al. (2015), Arrigoni (2016, 2017, 2018, 2019), Edwards (2017), Badalamenti and La Mantia (2018), Badalamenti et al. (2018), Cibei (2018a, 2018b), De Santis (2018a, 2018b, 2018c, 2018d), Englmaier and Wilhalm (2018), Lazzeri et al. (2018), Longo (2018), Manni (2018), Martini (2018), Nicolella (2018a, 2018b), Ottonello and Longo (2018a, 2018b, 2018c, 2018d), Pasta and Troia (2018), Pignatti (2018), Roma-Marzio et al. (2018), Stinca et al. (2018), Turland et al. (2018), Wilhalm et al. (2018), Bartolucci et al. (2019), Bovio (2019), Englmaier (2019), Lastrucci et al. (2019), Prosser et al. (2019), Stinca (2019), and corrections to Galasso et al. (2018a) are provided in Suppl. material 1.

G. Galasso, F. Bartolucci

\section{Acknowledgements}

We gratefully acknowledge Enrico Banfi and Daniela Longo, who provided distribution, nomenclatural and taxonomic suggestions.

\section{References}

Anzalone B, Iberite M, Lattanzi E (2010) La flora vascolare del Lazio. Informatore Botanico Italiano 42(1): 187-317.

Arrigoni PV (2016) Flora analitica della Toscana, Vol. 1. Edizioni Polistampa, Firenze.

Arrigoni PV (2017) Flora analitica della Toscana, Vol. 2. Edizioni Polistampa, Firenze.

Arrigoni PV (2018) Flora analitica della Toscana, Vol. 3. Edizioni Polistampa, Firenze. 
Arrigoni PV (2019) Flora analitica della Toscana, Vol. 5. Edizioni Polistampa, Firenze.

Arrigoni PV, Viegi L (2011) La flora vascolare esotica spontaneizzata della Toscana. Regione Toscana, Direzione generale Politiche territoriali, ambientali e per la mobilità, Settore Tutela e valorizzazione delle risorse ambientali, Firenze.

Badalamenti E, Cusimano D, La Mantia T, Pasta S, Romano S, Troia A, Ilardi V (2018) The ongoing naturalisation of Eucalyptus spp. in the Mediterranean basin: new threats to native species and habitats. Australian Forestry 81(4): 239-249. https://doi.org/10.1080/00049 158.2018.1533512

Badalamenti E, La Mantia T (2018) Handroanthus heptaphyllus (Bignoniaceae) in Sicily: a new casual alien to Italy and Europe. Flora Mediterranea 28: 331-338. https://doi.org/10.7320/ FlMedit28.331

Banfi E, Galasso G (Eds) (2010) La flora esotica lombarda. Museo di Storia Naturale di Milano, Milano, 274 pp. [+ CD-Rom]

Bartolucci F, Cancellieri L, Conti F, Banfi E, Bouvet D, Celestini M, Ciaschetti G, Di Pietro R, Falcinelli F, Fascetti S, Galasso G, Lattanzi E, Masin RR, Pennesi R, Rosati L, Stinca A, Tilia A, Forte TGW, Scoppola A (2019) Contribution to the floristic knowledge of Velino and Aterno valleys (Lazio-Abruzzo, central Italy). Italian Botanist 7: 93-100. https://doi. org/10.3897/italianbotanist.7.34697

Bovio M (Ed.) (2019) Note di aggiornamento al volume Flora vascolare della Valle d'Aosta - 5. Revue Valdôtaine d'Histoire Naturelle 72(2018): 97-121.

Calflora (2018) Calflora, information on wild California plants. https://www.calflora.org/ [accessed 03.12.2018]

Campus G, De Pascali M (2017) Rassegna di segnalazioni notevoli riguardanti la Sardegna comparse nel forum Acta Plantarum. Acta Plantarum Notes 5: 68-69.

Carine MA, Robba L (2010) Taxonomy and evolution of the Convolvulus sabatius complex (Convolvulaceae). Phytotaxa 14: 1-21. https://doi.org/10.11646/phytotaxa.14.1.1

Cecchi L, Selvi F (2017) Flora critica d'Italia. Boraginaceae - Boragineae. Fondazione per la Flora Italiana, Firenze. https://doi.org/10.17773/Fl_Ita_Boragineae1.0

Cesca G (1972) Ricerche citologiche ed embriologiche nel genere Euphorbia: Euphorbia oblongata Griseb. Tipografia dell'Università di Siena, Siena.

Chen Z, Wen J (2007) Parthenocissus Planchon. In: Wu ZY, Raven PH (Eds) Flora of China, Vol. 12. Science Press, Beijing, Missouri Botanical Garden Press, St. Louis, 173-177.

Chiovenda E (1920) L'Eragrostis caroliniana (Spreng.) Scribner. Bullettino della Società Botanica Italiana 1920(1-3): 11-16.

Cibei C (2018a) Notarella: 0212. Acta Plantarum Notes 6: 158.

Cibei C (2018b) Notarella: 0221. Acta Plantarum Notes 6: 167.

Crisafulli A, Picone RM, Zaccone S (2011) Phyllanthus tenellus (Phyllanthaceae) a new alien species naturalized to Sicily, first record for Italy. Flora Mediterranea 21: 293-297.

Cullen J, Knees SG, Cubey HS (2011) Palmae (Arecaceae). In: Cullen J, Knees SG, Cubey HS (Eds) The European garden flora. A manual for the identification of plants cultivated in Europe, both out-of-doors and under glass. Ed. 2, Vol. 1. Cambridge University Press, Cambridge, 361-372. 
DAISIE (2018) Physalis philadelphica. https://doi.org/10.1002/ejoc.201801400 [accessed $01.10 .2018]$

Danin A (2015) Commelina erecta L. In: Raab-Straube E von, Raus T (Eds) Euro+Med-Checklist Notulae, 4. Willdenowia 45(1): 124. https://doi.org/10.3372/wi.45.45113

Darst M, Gholson AK (2004) Noteworthy Collections. Florida. Castanea 69(4): 328. https:// doi.org/10.2179/0008-7475(2004)069<0328:F>2.0.CO;2

De Santis E (2018a) Contributo alla conoscenza della flora vascolare dei Monti della Tolfa (Lazio). La flora lungo il fiume Mignone nei pressi di Rota (Tolfa, RM). Acta Plantarum Notes 6: 58-72.

De Santis E (2018b) Notarella: 0203. Acta Plantarum Notes 6: 149.

De Santis E (2018c) Notarella: 0206. Acta Plantarum Notes 6: 152.

De Santis E (2018d) Notarella: 0209. Acta Plantarum Notes 6: 155.

Domina G, Mazzola P (2008) Flora ornamentale delle isole circumsiciliane. Quaderni di Botanica Ambientale e Applicata 19: 107-119.

Edwards D (2017) A new name for an Elaeagnus hybrid. The Plantsman 16(4): 222-223.

Englmaier P (2019) Alien grasses (Poaceae) in the flora of the eastern Alps: first supplement. Neilreichia 10: 185-189. http://doi.org/10.5281/zenodo.2630541

Englmaier P, Wilhalm T (2018) Alien grasses (Poaceae) in the flora of the eastern Alps: contribution to an excursion flora of Austria and the Eastern Alps. Neilreichia 9: 177-245. http://doi.org/10.5281/zenodo.1196285

European Commission (2014) Regulation (EU) No 1143/2014 of the European Parliament and of the Council of 22 October 2014 on the prevention and management of the introduction and spread of invasive alien species. http://eur-lex.europa.eu/legalcontent/EN/TX T/?qid=1468913651345\&uri=CELEX:32014R1143 [accessed 21.02.2019]

Everett TH (1982) The New York botanical garden illustrated encyclopedia of horticulture, Vol. 10: Ste-Zy. Garland Publishing Inc. New York, London.

Faden RB (2000) Commelinaceae. In: Flora of North America Editorial Committee (Ed.) Flora of North America North of Mexico, Vol. 22. Oxford University Press, New York, Oxford, $170-197$.

Farjon A (2017) A handbook of the world's conifers. Second, revised edition. Brill, Leiden, Boston. https://doi.org/10.1163/9789004324510

Fish L, Mashau AC, Moeaha MJ, Nembudani MT (2015) Identification guide to southern African grasses. Strelitzia 36: 271-276.

Flora Zambesiaca (2018) Key to Physalis. http://apps.kew.org/efloras/key.do?parentkey$\mathrm{id}=2368 \&$ keyid=2374 [accessed 11.11.2018]

Fryer J, Hylmö B, Zika PF (2014) Cotoneaster Medikus. In: Flora of North America Editorial Committee (Ed.) Flora of North America North of Mexico, Vol. 9. Oxford University Press, New York, Oxford, 448-468.

Galasso G, Conti F, Peruzzi L, Ardenghi NMG, Banfi E, Celesti-Grapow L, Albano A, Alessandrini A, Bacchetta G, Ballelli S, Bandini Mazzanti M, Barberis G, Bernardo L, Blasi C, Bouvet D, Bovio M, Cecchi L, Del Guacchio E, Domina G, Fascetti S, Gallo L, Gubellini L, Guiggi A, Iamonico D, Iberite M, Jiménez-Mejías P, Lattanzi E, Marchetti D, Marti- 
netto E, Masin RR, Medagli P, Passalacqua NG, Peccenini S, Pennesi R, Pierini B, Podda L, Poldini L, Prosser F, Raimondo FM, Roma-Marzio F, Rosati L, Santangelo A, Scoppola A, Scortegagna S, Selvaggi A, Selvi F, Soldano A, Stinca A, Wagensommer RP, Wilhalm T, Bartolucci F (2018a) An updated checklist of the vascular flora alien to Italy. Plant Biosystems 152(3): 556-592. https://doi.org/10.1080/11263504.2018.1441197

Galasso G, Domina G, Adorni M, Ardenghi NMG, Banfi E, Bedini G, Bertolli A, Brundu G, Calbi M, Cecchi L, Cibei C, D’Antraccoli M, De Bastiani A, Faggi G, Ghillani L, Iberite M, Latini M, Lazzeri V, Liguori P, Marhold K, Masin R, Mauri S, Mereu G, Nicolella G, Olivieri N, Peccenini S, Perrino EV, Peruzzi L, Petraglia A, Pierini B, Prosser F, RomaMarzio F, Romani R, Sammartino F, Selvaggi A, Signorile G, Stinca A, Verloove F, Nepi C (2016) Notulae to the Italian alien vascular flora: 1. Italian Botanist 1: 17-37. https://doi. org/10.3897/italianbotanist.1.8777

Galasso G, Domina G, Alessandrini A, Ardenghi NMG, Bacchetta G, Ballelli S, Bartolucci F, Brundu G, Buono S, Busnardo G, Calvia G, Capece P, D’Antraccoli M, Di Nuzzo L, Fanfarillo E, Ferretti G, Guarino R, Iamonico D, Iberite M, Latini M, Lazzaro L, Lonati M, Lozano V, Magrini S, Mei G, Mereu G, Moro A, Mugnai M, Nicolella G, Nimis PL, Olivieri N, Pennesi R, Peruzzi L, Podda L, Probo M, Prosser F, Ravetto Enri S, Roma-Marzio F, Ruggero A, Scafidi F, Stinca A, Nepi C (2018b) Notulae to the Italian alien vascular flora: 6. Italian Botanist 6: 65-90. https://doi.org/10.3897/italianbotanist.6.30560

Gibbs Russell GE, Watson L, Koekemoer M, Smook L, Barker NP, Anderson HM, Dallwitz MJ (1990) Grasses of southern Africa. Memoirs of the Botanical Survey of South Africa 58: 1-437.

Gildenhuys E, Ellis AG, Carroll SP, Le Roux JJ (2013) The ecology, biogeography, history and future of two globally important weeds: Cardiospermum halicacabum Linn. and C. grandiflorum Sw. NeoBiota 19: 45-65. https://doi.org/10.3897/neobiota.19.5279

Govaerts R, Kington S, Friesen N, Fritsch R, Snijman DA, Marcucci R, Silverstone-Sopkin PA, Brullo S (2018) World checklist of Amaryllidaceae. Facilitated by the Royal Botanic Gardens, Kew. http://wcsp.science.kew.org [accessed 11.11.2018]

Herman PPJ (2003) Dimorphotheca Vaill. ex Moench. In: Germishuizen G, Meyer NL (Eds) Plants of southern Africa: an annotated checklist. Strelitzia 14: 211-212.

Hinojosa-Espinosa O, Villaseñor JL (2015) Arctotheca prostrata (Asteraceae: Arctotideae), a South African species now present in Mexico. Botanical Sciences 93(4): 1-4. https://doi. org/10.17129/botsci.223

Holm LG, Plucknett DL, Pancho JV, Herberger JP (1977) The world's worst weeds. Distribution and biology. University Press of Hawaii, Honolulu.

Kumar B (2011) Commelina erecta. The IUCN red list of threatened species 2011: e.T176972A7342930. [accessed 15.10.2018] https://doi.org/10.2305/IUCN.UK.2011-1. RLTS.T176972A7342930.en

Lastrucci L, Dell'Olmo L, Foggi B, Massi L, Nuccio C, Vicenti C, Viciani D (2017a) Contribution to the knowledge of the vegetation of the Lake Massaciuccoli (northern Tuscany, Italy). Plant Sociology 54(1): 67-87. https://doi.org/10.7338/pls2017541/03

Lastrucci L, Fiorini G, Lunardi L, Viciani D (2019) Herbarium survey on the genus Azolla (Salviniaceae) in Italy: distributive and taxonomic implications. Plant Biosystems. https:// doi.org/10.1080/11263504.2018.1549601 
Lastrucci L, Foggi B, Becattini R (2006) Myriophyllum aquaticum (Vell.) Verdc. (Haloragaceae): una nuova specie esotica invasiva per la Toscana. Informatore Botanico Italiano 37(2) [2005]: 1133-1136.

Lastrucci L, Lazzaro L, Dell'Olmo L, Foggi B, Cianferoni F (2017b) Impacts of Myriophyllum aquaticum invasion in a Mediterranean wetland on plant and macro-arthropod communities. Plant Biosystems 152(3) [2018]: 427-435. https://doi.org/10.1080/11263504.2017 .1303002

Lastrucci L, Valentini E, Dell'Olmo L, Vietina B, Foggi B (2016) Hygrophilous vegetation and habitats of conservation interest in the area of the Lake Porta (Tuscany, Central Italy). Atti della Società Toscana di Scienze Naturali, Memorie, Serie B 122(2015): 131-146. https:// doi.org/10.2424/ASTSN.M.2015.12

Lazzeri V, Gestri G, Borzatti von Löwenstern A, Mannocci M, Barsotti G, Campus G, Caramante P (2018) Note floristiche tosco-sarde IV: novità regionali e locali per le regioni Toscana e Sardegna. Annali del Museo Civico di Rovereto. Sezione: Archeologia, Storia Scienze Naturali 33 (2017): 79-110.

Longo D (2018) Notarella: 0216. Acta Plantarum Notes 6: 162.

Lu LT, Brach AR (2003) Cotoneaster Linnaeus. In: Wu ZY, Raven PH (Eds) Flora of China, Vol. 9. Science Press, Beijing, Missouri Botanical Garden Press, St. Louis, 85-108.

Lucchese F (2010) Molise. In: Celesti-Grapow L, Pretto F, Carli E, Blasi C (Eds) Flora vascolare alloctona e invasiva delle regioni d'Italia. Casa Editrice Università La Sapienza, Roma, 114-118.

Lucchese F (Ed.) (2017) Atlante della flora alloctona del Lazio: cartografia, ecologia e biogeografia. Vol. 1: Parte generale e flora alloctona. Regione Lazio, Direzione Ambiente e Sistemi Naturali, Roma.

Mahoney AM, McKenzie RJ (2012) Arctotheca. In: Jepson Flora Project (Eds) Jepson eFlora. http://ucjeps.berkeley.edu/eflora/eflora_display.php?tid=77538 [accessed 24.12.2018]

Maniero F (2015) Cronologia della flora esotica italiana. Leo S. Olschki, Firenze.

Manni QG (2018) Notarella: 0237. Acta Plantarum Notes 6: 183.

Marchessi JE, Subils R, Scaramuzzino RL, Crosta HN, Eseiza MF, Saint André HM, Juan VF (2011) Presencia de Euphorbia davidii Subils (Euphorbiaceae) en la Provincia de Buenos Aires: morfología y anatomía de la especie. Kurtziana 36(1): 45-53.

Martini F (Ed.) (2018) Aggiornamenti alla flora del Friuli Venezia Giulia (Italia nordorientale). Nuova serie. III (65-84). Gortania. Botanica, Zoologia 37 (2017): 19-28.

McAllister HA, Rutherford A (1990) Hedera helix L. and H. hibernica (Kirchner) Bean (Araliaceae) in the British Isles. Watsonia 18(1): 7-15.

McLean P, Wilson JRU, Gaertner M, Kritzinger-Klopper S, Richardson DM (2018) The distribution and status of alien plants in a small South African town. South African Journal of Botany 117: 71-78. https://doi.org/10.1016/j.sajb.2018.02.392

Mito T, Uesugi T (2004) Invasive alien species in Japan: the status quo and the new regulation for prevention of their adverse effects. Global Environmental Research 8(2): 171-191.

New England Wild Flower Society (2018) Physalis. In: Go Botany. https://gobotany.newenglandwild.org/dkey/physalis/ [accessed 11.11.2018] 
Nicolella G (2018a) Notarella: 0205. Acta Plantarum Notes 6: 151.

Nicolella G (2018b) Notarella: 0208. Acta Plantarum Notes 6: 154.

Nordenstam B (2007) Tribe Calenduleae Cass. (1819). In: Kadereit JW, Jeffrey C (Eds) The families and genera of vascular plants, Vol. 8. Springer, Berlin, Heidelberg, 241-245.

Ottonello M, Longo D (2018a) Notarella: 0213. Acta Plantarum Notes 6: 159.

Ottonello M, Longo D (2018b) Notarella: 0214. Acta Plantarum Notes 6: 160.

Ottonello M, Longo D (2018c) Notarella: 0222. Acta Plantarum Notes 6: 168.

Ottonello M, Longo D (2018d) Notarella: 0223. Acta Plantarum Notes 6: 169.

Pandža M (2017) Alien flora of the settlement of Jezera on the island Murter (Dalmatia, Croatia). Agronomsky Glasnik 3: 121-148. https://doi.org/10.33128/ag.79.3.4

Pasta S, La Rosa A, La Mantia T, Badalamenti E (2016) Anredera cordifolia (Ten.) Steenis (Basellaceae): status in Italia e sua espansione in Sicilia occidentale. Il Naturalista Siciliano s. 4, 40(1): 145-149.

Pasta S, Troia A (2018) From common and used to rare and forgotten: past and present distribution of the archaeophyte Euphorbia lathyris L. (Euphorbiaceae) in southern Italy and Sicily. Atti della Società Toscana di Scienze Naturali, Memorie, Serie B.

Pavari A, De Philippis A (1941) La sperimentazione di specie forestali esotiche in Italia. Risultati del primo ventennio. Annali della Sperimentazione Agraria 38: 1-648.

Pedullà ML, Garbari F (2002) Piante d'interesse biogeograficoecologico nei canali di bonifica della pianura pisana. Atti della Società Toscana di Scienze Naturali, Memorie, Serie B 108 (2001): 113-117.

Peruzzi L, Viciani D, Angiolini C, Astuti G, Avanzi A, Baldanzi C, Benesperi R, Bonari G, Bonini I, D’antraccoli M, Castellani B, Dell'Olmo L, Di Nuzzo L, Domina G, Ercolini P, Ferretti G, Fontana D, Gestri G, Gottschlich G, Grazzini A, Lastrucci L, Lazzaro L, Malfanti F, Marsiaj G, Piazzini S, Pierini B, Roma-Marzio F, Sani A, Selvi F, Vicenti C, Bedini G (2016) Contributi per una flora vascolare di Toscana. VII (357-439). Atti della Società Toscana di Scienze Naturali, Memorie, Serie B 122(2015): 61-72. https://doi. org/10.2424/ASTSN.M.2015.07

Pflugbeil G, Moosbrugger K (2016) Floristische Besonderheiten in der Stadt Salzburg und ihren Umlandgemeinden. Mitteilungen aus dem Haus der Natur 23: 58-71.

Pignatti S (2018) Flora d'Italia. Ed. 2, Vol. 3. Edagricole, Bologna.

Prosser F, Bertolli A, Festi F, Perazza G (2019) Flora del Trentino. Ed. Osiride, Fondazione Museo Civico, Rovereto (Trento).

Raabe U, Raus T (2016) Oenothera lindheimeri (Engelm. \& A. Gray) W. L. Wagner \& Hoch. In: Raab-Straube E von, Raus T (Eds) Euro+Med-Checklist Notulae, 6. Willdenowia 46(3): 430. https://doi.org/10.3372/wi.46.46310

Raimondo FM, Domina G, Spadaro V, Aquila G (2005) Prospetto delle piante avventizie e spontaneizzate in Sicilia. Quaderni di Botanica Ambientale e Applicata 15 (2004): 153-164.

Rehman S, Park I-H (2000) Effect of scarification, GA and chilling on the germination of goldenrain-tree (Koelreuteria paniculata Laxm.) seeds. Scientia Horticulturae 85(4): 319-324. https://doi.org/10.1016/S0304-4238(00)00126-6 
Roma-Marzio F, Lastrucci L, Guzzon F, Ardenghi NMG, Peruzzi L, Mossini S (2018) Nuove segnalazioni floristiche italiane 5. Flora vascolare (28-46). Notiziario della Società Botanica Italiana 2(2): 205-210.

Ross H (1899) Beitrage zur Flora von Sicilien. 1 Teil. Erläuterungen und kritische Bemerkungen zum Herbarium siculum. Centuria I. Bulletin de l'Herbier Boissier 7(4): 262-299.

Rostański K, Verloove F (2015) The genus Oenothera (Onagraceae) in Belgium. Dumortiera 106: $12-42$.

Sánchez Gullón E, Verloove F (2015) New records of interesting xenophytes in the Iberian Peninsula. V. Lazaroa 36: 43-50. https://doi.org/10.5209/rev_LAZA.2015.v36.48752

Schoenenberger N, Röthlisberger J, Carraro G (2014) La flora esotica del Cantone Ticino (Svizzera). Bollettino della Società Ticinese di Scienze Naturali 102: 13-30.

Singh G, Singh OP, De Lampasona MP, Catalán CA (2003) Studies on essential oils. Part 35: chemical and biocidal investigations on Tagetes erecta leaf volatile oil. Flavour and Fragrance Journal 18(1): 62-65. https://doi.org/10.1002/ff.1158

Soldano A, Verloove F (2013) Nota floristica piemontese n. 531. Physalis viscosa L. (Solanaceae). In: Selvaggi A, Soldano A, Pascale M, Dellavedova R (Eds) Note Floristiche Piemontesi n. 460-544. Rivista Piemontese di Storia Naturale 34: 403.

Spadaro V, Raimondo FM (2017) Stazioni nuove di Euphorbia hypericifolia (Euphorbiaceae) e di Phyllanthus tenellus (Phyllanthaceae) in Sicilia. Quaderni di Botanica Ambientale e Applicata 26 (2015): 39-42.

Squire D (2007) Palms and Cycads. A complete guide to selecting, growing and propagating. New Holland Publishers Ltd., London.

Stinca A (2019) The genus Vitis L. (Vitaceae) in Campania (southern Italy), with emphasis on alien units. Annali di Botanica 9: 107-112. https://doi.org/10.13133/2239-3129/14792

Stinca A, Ravo M, Giacanelli V, Conti F (2018) Additions to the vascular flora of the islands of Procida and Vivara (Campania, southern Italy). Atti della Società Toscana di Scienze Naturali, Memorie, Serie B 125: 87-93. https://doi.org/10.2424/ASTSN.M.2018.14

Stokes CA, MacDonald GE, Adams CR, Langeland KA, Miller DL (2011) Seed biology and ecology of natalgrass (Melinis repens). Weed Science 59(4): 527-532. https://doi. org/10.1614/WS-D-11-00028.1

Tison JM (2012) Oenothera lindheimeri (Engelm. \& A.Gray) W.L.Wagner \& Hoch. In: Jeanmonod D, Schlüssel A (Eds) Notes et contributions à la flore de Corse, XXIV. Candollea 67(2): 316. https://doi.org/10.15553/c2012v672a11

Turland NJ, Wiersema JH, Barrie FR, Greuter W, Hawksworth DL, Herendeen PS, Knapp S, Kusber W-H, Li D-Z, Marhold K, May TW, McNeill J, Monro AM, Prado J, Price MJ, Smith GF (Eds) (2018) International Code of Nomenclature for algae, fungi, and plants (Shenzhen Code) adopted by the Nineteenth International Botanical Congress Shenzhen, China, July 2017. Regnum Vegetabile 159: 1-254. https://doi.org/10.12705/Code.2018

Verloove F (2019) Parthenocissus tricuspidata. In: Manual of the alien plants of Belgium. Botanic Garden Meise, Belgium. http://alienplantsbelgium.be/species-list/parthenocissustricuspidata [accessed 05.01.2019] 
Verloove F, Sánchez Gullón E (2012) New records of interesting vascular plants (mainly xenophytes) in the Iberian Peninsula. II. Flora Mediterranea 22: 5-24. https://doi.org/10.7320/ FlMedit22.005

Viegi L, Cela Renzoni G (1981) Flora esotica d'Italia: le specie presenti in Toscana. Consiglio Nazionale delle Ricerche, Collana «Promozione della qualità dell'ambiente», Pavia, AQ/1/132.

Viggiani P (2015) L'americana Euphorbia davidii sulla soia italiana. Terra e Vita 56(46): 58-61.

Wang ZQ, Guillot D, Ren MX, López-Pujol J (2016) Kalanchoe (Crassulaceae) as invasive aliens in China - new records, and actual and potential distribution. Nordic Journal of Botany 34(3): 349-354. https://doi.org/10.1111/njb.01052

Ward DB (2008) Keys to the flora of Florida: 18, Kalanchoe (Crassulaceae). Phytologia 90(1): $41-46$.

Wilhalm T, Aichner G, Argenti C, Bucher E, Egger W, Fink M, Girardi E, Hilpold A, Hofer G, Kiebacher T, Mallaun M, Prosser F, Rinner A, Sölva E, Stockner W, Thalinger M, Tratter W, Unterluggauer P, Winkler J, Zemmer F (2018) Ergänzungen und Korrekturen zum Katalog der Gefäßpflanzen Südtirols (8). Gredleriana 18: 5-16.

Wood JRI, Williams BRM, Mitchell TC, Carine MA, Harris DJ, Scotland RW (2015) A foundation monograph of Convolvulus L. (Convolvulaceae). PhytoKeys 51: 1-282. https://doi. org/10.3897/phytokeys.51.7104

Yan XL, Liu QR, Shou HY, Zeng XF, Zhang Y, Chen L, Liu Y, Ma HY, Qi SY, Ma JS (2014) The categorization and analysis on the geographic distribution patterns of Chinese alien invasive plants. Biodiversity Science 22(5): 667-676. https://doi.org/10.3724/ SP.J.1003.2014.140699

\section{Supplementary material I}

\section{Supplementary data}

Edited by: Gabriele Galasso, Fabrizio Bartolucci

Data type: species data

Explanation note: 1. Nomenclatural updates; 2. Distribution updates; 3. Synonyms, misapplied or included names.

Copyright notice: This dataset is made available under the Open Database License (http://opendatacommons.org/licenses/odbl/1.0/). The Open Database License $(\mathrm{ODbL})$ is a license agreement intended to allow users to freely share, modify, and use this Dataset while maintaining this same freedom for others, provided that the original source and author(s) are credited.

Link: https://doi.org/10.3897/italianbotanist.7.36386.suppl1 